\title{
Characterization of the tyramine-producing pathway in Sporolactobacillus sp. P3J
}

\author{
Monika Coton, ${ }^{1}$ María Fernández, ${ }^{2}$ Hein Trip, ${ }^{3}$ Victor Ladero, ${ }^{2}$ \\ Niels L. Mulder, ${ }^{3}$ Juke S. Lolkema, ${ }^{3}$ Miguel A. Alvarez ${ }^{2}$ \\ and Emmanuel Coton ${ }^{1} \dagger$
}

Correspondence
Emmanuel Coton
emmanuel.coton@univ-brest.fr

Received 22 October 2010

Revised 2 March 2011

Accepted 16 March 2011

\author{
${ }^{1}$ ADRIA Normandie, Boulevard du 13 Juin 1944, 14310 Villers-Bocage, France \\ ${ }^{2}$ Instituto de Productos Lácteos de Asturias, CSIC, Carretera de Infiesto s/n, 33300 Villaviciosa, \\ Asturias, Spain \\ ${ }^{3}$ Molecular Microbiology, Groningen Biomolecular Sciences and Biotechnology Institute, \\ University of Groningen, Haren, The Netherlands
}

\begin{abstract}
A sporulated lactic acid bacterium (LAB) isolated from cider must was shown to harbour the $t d c$ gene encoding tyrosine decarboxylase. The isolate belonged to the Sporolactobacillus genus and may correspond to a novel species. The ability of the $t d c$-positive strain, Sporolactobacillus sp. strain P3J, to produce tyramine in vitro was demonstrated by using HPLC. A 7535 bp nucleotide sequence harbouring the putative $t d c$ gene was determined. Analysis of the obtained sequence showed that four tyramine production-associated genes [tyrosyl-tRNA synthetase (tyrS), tyrosine decarboxylase $(t d c)$, tyrosine permease $(t y r P)$ and $\mathrm{Na}^{+} / \mathrm{H}^{+}$antiporter $\left.(n h a C)\right]$ were present and were organized as already described in other tyramine-producing LAB. This operon was surrounded by genes showing the highest identities with mobile elements: a putative phage terminase and a putative transposase (downstream and upstream, respectively), suggesting that the tyramine-forming trait was acquired through horizontal gene transfer. Transcription analyses of the $t d c$ gene cluster suggested that $t y r S$ and $n h a C$ are expressed as monocistronic genes while $t d c$ would be part of a polycistronic mRNA together with tyrP. The presence of tyrosine in the culture medium induced the expression of all genes except for tyrS. A clear correlation was observed between initial tyrosine concentration and tyramine production combined with an increase in the final $\mathrm{pH}$ reached by the culture. Finally, cloning and expression of the tyr $P$ gene in Lactococcus lactis demonstrated that its product catalyses the exchange of tyrosine and tyramine.
\end{abstract}

\section{INTRODUCTION}

Biogenic amines (BA) are low-molecular-mass molecules with at least one amine group that can be accumulated in foods (e.g. fish, cheese, wine, sausages, cider) (Chang et al., 1985; ten Brink et al., 1990; Lonvaud-Funel, 2001; Suzzi \& Gardini, 2003; Garai et al., 2006) due to the presence of BAforming micro-organisms during elaboration processes or

†Present address: Laboratoire Universitaire de Biodiversité et Ecologie Microbienne (EA3882), IFR148 SclnBioS, Université Européenne de Bretagne, Université de Brest, ESMISAB, Technopôle de Brest Iroise, 29280 Plouzané, France.

Abbreviations: BA, biogenic amines; LAB, lactic acid bacteria; RS-PCR, restriction site-PCR; RT-qPCR, real-time RT-PCR; TDC, tyramine decarboxylase.

The GenBank/EMBL/DDBJ accession number for the 7535 bp RSPCR-generated sequence obtained in this study is HQ285999.

A supplementary table of primer sequences is available with the online version of this paper. storage. The consumption of foods containing high concentrations of BA may be associated with health effects in sensitive consumers (Ladero et al., 2010). The main BAs studied are histamine and tyramine due to their greater physiological actions and toxicological effects (Caston et al., 2002; Wallace, 2007). In fact, the term 'cheese reaction' has been coined to refer to the symptoms induced after ingestion of cheeses with elevated tyramine concentrations. However, the concentration of histamine is regulated for some fish by the USA Food and Drug Administration and EU legislation [Commission Regulation (EC) no. 2073/2005].

$\mathrm{BA}$ are produced in food matrices containing free amino acids via intracellular bacterial catabolic pathways that consist of at least a decarboxylase and a transporter responsible for the uptake of the amino acid (i.e. histidine, tyrosine) and the excretion of the corresponding amine (i.e. histamine, tyramine). These decarboxylation reactions have been proposed as metabolic energy-generating pathways via a proton motive force (Molenaar et al., 1993; 
Wolken et al., 2006) and/or as stress response mechanisms (Fritz et al., 2009). In order to better understand the origin of BA production in fermented foods, a number of studies have been performed to not only identify the microorganisms able to form these molecules (Burdychova \& Komprda, 2007; Bover-Cid et al., 2009; Garai et al., 2007; Coton et al., 2010b; Moon et al., 2010) but also characterize the operons responsible for these activities (i.e. Linares et al., 2009). Over the past few years, BA pathways in lactic acid bacteria (LAB) have been described to be straindependent rather than species-specific and horizontal gene transfer was suggested for the acquisition of the gene clusters involved in the production of histamine by Lactobacillus hilgardii (Lucas et al., 2005), tyramine by Lactobacillus brevis (Coton \& Coton, 2009) and putrescine by Oenococcus oeni (Marcobal et al., 2006).

Concerning the tyramine pathway, Lucas et al. (2003) described that in L. brevis IOEB 9809, the tyramine decarboxylase (TDC) pathway is encoded by a cluster consisting of four genes. The first gene (tyrS) shows strong similarities with tyrosyl-tRNA synthetase genes, the second gene $(t d c)$ corresponds to the tyrosine decarboxylase, the third gene $(\operatorname{tyr} P)$ encodes a tyrosine/tyramine exchanger (Wolken et al., 2006), while the last gene (nhaC) is related to the $\mathrm{Na}^{+} / \mathrm{H}^{+}$antiporter genes. The existence of the same gene organization has been described in other tyramineproducing LAB, Enterococcus faecalis (Connil et al., 2002), Enterococcus hirae (Coton et al., 2004), Enterococcus durans (Fernández et al., 2004) and Enterococcus faecium (GenBank accession no. NZ_AAAK00000000).

In this study, the origin and some functional properties of the tyramine-forming ability of Sporolactobacillus sp. strain P3J, isolated from French cider, were investigated.

\section{METHODS}

Bacterial strains and culture conditions. Sporolactobacillus sp. strain P3J was originally isolated on de Man, Rogosa \& Sharpe medium (MRS) (AES) from a sample from cider from the Perche area (Orne, France) (Coton et al., 2010b). Sporolactobacillus kofuensis (DSM $17615^{\mathrm{T}}$ ), Sporolactobacillus nakayamae subsp. nakayamae (DSM 11696 ${ }^{\mathrm{T}}$ ), Sporolactobacillus terrae (DSM 11697 $7^{\mathrm{T}}$ ) and Sporolactobacillus vineae (DSM $21990^{\mathrm{T}}$ ) were obtained from DSMZ. All strains were grown in glucose yeast peptone medium (GYP, Chen et al., 2005) adjusted to $\mathrm{pH} 6.8$ and cultures were incubated for $48 \mathrm{~h}$ (broth) or 3-5 days (agar). When necessary, GYP was supplemented with tyrosine $(1,5$ or $10 \mathrm{mM}$, Sigma) $(\mathrm{GYP}+\mathrm{T})$.

Preparation of template DNA and RNA. Total DNA was extracted from $1 \mathrm{ml}$ overnight bacterial culture with the Nucleospin tissue kit (Macherey-Nagel) according to the manufacturer's instructions (50100 ng DNA was used in all PCR experiments).

Total RNA was extracted using the TRI Reagent (Sigma) as follows. Sporolactobacillus sp. cells were grown in GYP and GYP + T at pH 5.0 until $\mathrm{OD}_{600} \sim 0.6$. They were then harvested by centrifugation and disrupted using glass beads (diameter up to $106 \mu \mathrm{m}$, Sigma) in a FastPrep FP120 Instrument (MP Biomedicals) at $4{ }^{\circ} \mathrm{C}$, six times for $30 \mathrm{~s}$ at power setting 6 . The resulting samples were treated as recommended by the manufacturer. Purified RNA was resuspended in $0.1 \%$ diethyl pyrocarbonate (DEPC)-treated water. Total RNA concentrations were determined by UV spectrophotometry by measuring absorbance at $260 \mathrm{~nm}$ in an Epoch spectrophotometer (Biotek).

PCR amplification. Detection of the $t d c$ gene in the different Sporolactobacillus sp. strains was performed using the PCR method described by Coton et al. (2004). For strain identification, the $16 \mathrm{~S}$ rRNA gene fragment was obtained after PCR amplification using the universal primers BSF8/BSR1541 (Edwards et al., 1989) as described previously (Coton \& Coton, 2005).

Acquisition of unknown sequences adjacent to the $t d c$ gene was performed as described by Coton et al. (2010a). Briefly, the method corresponded to the restriction site-PCR (RS-PCR) described by Sarkar et al. (1993) with a single modification: PCR primers corresponding to the known sequence used for the second PCR were also used for sequencing. All PCR experiments were performed in a Mastercycler Gradient PCR machine (Eppendorf).

Aliquots $(18 \mu \mathrm{l}$ for PCR products and $9 \mu \mathrm{l}$ for RS-PCR-generated fragments) of each PCR sample were analysed using $0.8 \%(\mathrm{w} / \mathrm{v})$ agarose gels (Invitrogen) in $1 \times \mathrm{TBE}$ buffer at $130 \mathrm{~V}$ for $50 \mathrm{~min}$ then visualized with ethidium bromide using a GelDoc2000 and the Quantity One software (Bio-Rad).

DNA sequencing and sequence analysis. The $16 \mathrm{~S} \mathrm{rDNA}, t d c$ and RS-PCR products were purified using the GenElute PCR purification kit (Sigma) and sequenced by Eurofins MWG Operon (Germany). Alignments were performed using the Bionumerics software (Applied Maths). Sequence comparisons against international databases were performed using BLAST (Altschul et al., 1990). Theoretical molecular mass and isoelectrical point were estimated by the Compute $\mathrm{pI} / \mathrm{Mw}$ tool (http://www.expasy.ch/tools/pi_tool.html), while conserved domains were identified by the NCBI Conserved Domain Search tool (http://www.ncbi.nlm.nih.gov/Structure/cdd/wrpsb.cgi).

RT-PCR. RNA samples ( $2 \mu \mathrm{g}$ total RNA) were treated with $2 \mathrm{U}$ DNase I (Fermentas) to eliminate any DNA contamination. The absence of contaminating DNA in the DNase-treated RNA samples was controlled by PCR performed under the same conditions but without reverse transcriptase. cDNA was then synthesized from total RNA using the high capacity C-DNA reverse transcription kit (Applied Biosystems) following the manufacturer's recommendations. PCRs were performed using $2 \mu \mathrm{lDNA}$ suspension and $0.4 \mu \mathrm{M}$ each primer (Supplementary Table S1, available with the online version of this paper). The amplifications were performed for 35 cycles $\left(94{ }^{\circ} \mathrm{C}\right.$ for $30 \mathrm{~s}, 55{ }^{\circ} \mathrm{C}$ for $1 \mathrm{~min}$ and $72{ }^{\circ} \mathrm{C}$ for $\left.1 \mathrm{~min}\right)$ and the resulting fragments were electrophoretically analysed in $1.5 \%$ agarose gels in TAE buffer (40 mM TRIS/acetate, 1 mM EDTA, pH 8.0).

Quantification of gene expression by real-time RT-PCR (RTqPCR). Gene expression was analysed by RT-qPCR as previously described for O. oeni (Desroche et al., 2005), using the SYBR Green PCR master mix (Applied Biosystems) in a 7500 Fast Real-Time PCR System (Applied Biosystems). Four different dilutions of cDNA were tested. Five microlitres of each solution was added to $20 \mu \mathrm{l} \mathrm{PCR}$ mixture $(12.5 \mu \mathrm{l} \mathrm{SYBR}$ Green Supermix, $1 \mu \mathrm{l}$ each primer at $7 \mu \mathrm{M}$ and $5.5 \mu$ RNase-free water). All cDNAs were amplified by RT-qPCR using specific primers (Supplementary Table S1) selected using Primer Express software (Applied Biosystems) and designed to produce amplicons of similar length (approx. $100 \mathrm{bp}$ ). The gene encoding the 16S rRNA was used as an internal control to normalize the RNA concentration. In each run, a negative and a positive control were included. Amplifications were performed using the default cycling settings established by Applied Biosystems.

The number of PCR cycles required to reach the midpoint of the amplification curve (cycle threshold or $\mathrm{C}_{\mathrm{T}}$ ) was measured to compare 
gene expression. To relate $C_{T}$ values to the abundance of mRNA species, they were converted into ' $n$-fold differences' $(y)$ using the formula $y=2^{\Delta \Delta \mathrm{CT}}$ (Livak \& Schmittgen, 2001). The condition with the lower level of expression was selected as the calibrator. For each gene, RT-qPCR analysis was performed on RNA purified from three independent cultures grown under each of the environmental conditions assayed.

Cloning and expression of tyrP. The tyrP gene was amplified by PCR from genomic DNA of Sporolactobacillus sp. P3J using primer tyrP-Spfw $\left(5^{\prime}\right.$ - GCGAGACCATGGAAAAGAACTTGGCCCAAAAGG-3') and tyrP-Sp-rv (5' -GCGAAATCTAGATCAAAGAGGGCTGCCCGTAG$3^{\prime}$ ), introducing $\mathrm{NcoI}$ and $\mathrm{XbaI}$ restriction sites. The $1.61 \mathrm{~kb}$ product was ligated into the NICE system expression vector pNZ8048 to yield pNZtyrP-Sp, which was transformed to Lactococcus lactis NZ9000 (de Ruyter et al., 1996). For expression of tyrP, L. lactis NZ9000 pNZtyrP$\mathrm{Sp}$ was grown on M17 medium supplied with $0.5 \%$ glucose and $5 \mathrm{ng}$ chloramphenicol ml $\mathrm{ml}^{-1}$ to mid-exponential growth phase $\left(\mathrm{OD}_{600} 0.6\right)$ at $30{ }^{\circ} \mathrm{C}$. Nisin was added to a final concentration of $5 \mathrm{ng} \mathrm{ml}^{-1}$ to induce expression and cells were left to grow for another $1 \mathrm{~h}$.

Tyrosine and tyramine transport assays. L. lactis NZ9000 cells expressing tyrP from pNZtyrP-Sp were harvested and washed in $100 \mathrm{mM}$ potassium phosphate (KPi) buffer, $\mathrm{pH} 6.0$ and resuspended in the same buffer to $\mathrm{OD}_{600} 2.0$. Glucose was added to $10 \mathrm{mM}$ and $100 \mu \mathrm{l}$ samples were incubated at $30{ }^{\circ} \mathrm{C}$ with constant stirring. After 5 min preincubation, ${ }^{14} \mathrm{C}$-labelled tyrosine (Amersham Pharmacia) or tyramine (American Radiolabelled Chemicals) was added to a final concentration of 1.15 or $18 \mu \mathrm{M}$, respectively. Uptake was stopped by addition of $2 \mathrm{ml}$ ice-cold $0.1 \mathrm{M} \mathrm{LiCl}$ followed by filtration through a $0.45 \mathrm{~mm}$ pore-size nitrocellulose filter (BA85; Schleicher \& Schuell). The filter was washed once with $2 \mathrm{ml}$ ice-cold $0.1 \mathrm{M} \mathrm{LiCl}$ and submerged in Emulsifier Scintillator Plus scintillation fluid (Packard Bioscience). Retained radioactivity was counted in a Tri-Carb 2000CA liquid scintillation analyser (Packard Instrumentation). In the exchange experiment, unlabelled tyramine was added to cells to a final concentration of $1 \mathrm{mM}, 1 \mathrm{~min}$ after the addition of ${ }^{14} \mathrm{C}$-labelled tyrosine. For preloading of cells with tyrosine, cells were resuspended in $100 \mathrm{mM}$ KPi buffer, $\mathrm{pH} 6.0$, containing $5 \mathrm{mM}$ tyrosine and left at room temperature for $1 \mathrm{~h}$. Cells were washed three times with $100 \mathrm{mM} \mathrm{KPi}$ buffer, $\mathrm{pH}$ 6.0, prior to the uptake experiment at $4{ }^{\circ} \mathrm{C}$.

Detection of biogenic amines by HPLC. Quantitative analysis of tyramine production was carried out by reverse-phase HPLC using a computer-controlled (Millenium 32, Waters) liquid chromatograph (Alliance 2695, Waters). The strain was grown in GYP $+\mathrm{T}$ for $24 \mathrm{~h}$. The cultures were centrifuged at $8000 \mathrm{~g}$ for $10 \mathrm{~min}$, and the resulting supernatants were filtered using $0.2 \mu \mathrm{m}$ PTFE membranes (Supor). The resulting samples were derivatized using dabsyl chloride. Separations were carried out on reverse phase/C18 column (XTerra MS C18 $5 \mu \mathrm{m} 4.8 \times 150 \mathrm{~mm}$, Waters); gradient and detection conditions were as described by Krause et al. (1995).
Statistical analysis. All experiments were repeated at least three times. Mean values $\pm \mathrm{SD}$ are indicated. All statistical analyses were performed with the SPSS v11.0 software package (IBM).

\section{RESULTS}

\section{Strain identification}

The cider isolate P3J, obtained on MRS medium, corresponded to a Gram-positive bacterium and exhibited, for some cells, the presence of an endospore in the terminal position. Sequencing of a $1459 \mathrm{bp} 16 \mathrm{~S}$ rRNA gene fragment (GenBank accession no. HQ285998) indicated that the isolate belonged to the Sporolactobacillus genus. High identity levels $(96 \%)$ were observed with various Sporolactobacillus species [i.e. S. kofuensis (AJ634661), S. inulinus (AB362770) and S. laevolacticus (AB362650)] (Fig. 1). However, the identity levels observed did not allow for presumptive assigning of the P3J isolate to a defined Sporolactobacillus species; therefore, the strain was named Sporolactobacillus sp. P3J.

\section{Genotypic and phenotypic characterization of tyramine production by Sporolactobacillus sp. P3J}

Using a multiplex PCR method for the detection of four BA-associated genes ( $h d c, t d c, o d c$ and $a g d i)$, a specific band with a comparable size to the $t d c$ fragment of $L$. brevis IOEB 9809 ( 1100 bp) (data not shown) was amplified from Sporolactobacillus sp. P3J DNA (Coton et al., 2010b). The fragment obtained was sequenced using the TD2/TD5 primer set (Coton \& Coton, 2005) and the resulting $1133 \mathrm{bp}$ sequence was compared with international databases using BLAST (Altschul et al., 1990). The highest nucleotidic identities were observed with various tyrosine decarboxylase genes of Gram-positive bacteria, including $E$. hirae (AY303667), L. brevis ATCC 367 (CP000416) and Lactobacillus curvatus HSCC1737 (AB086652) (75, 75 and $74 \%$, respectively).

To confirm the ability of this strain to form tyramine in vitro, the supernatant of a $24 \mathrm{~h}$ Sporolactobacillus sp. P3J culture in GYP $+\mathrm{T}$ medium was also analysed by HPLC. The analysis revealed the production of $8.48 \mathrm{mM}$ tyramine in the tested conditions.

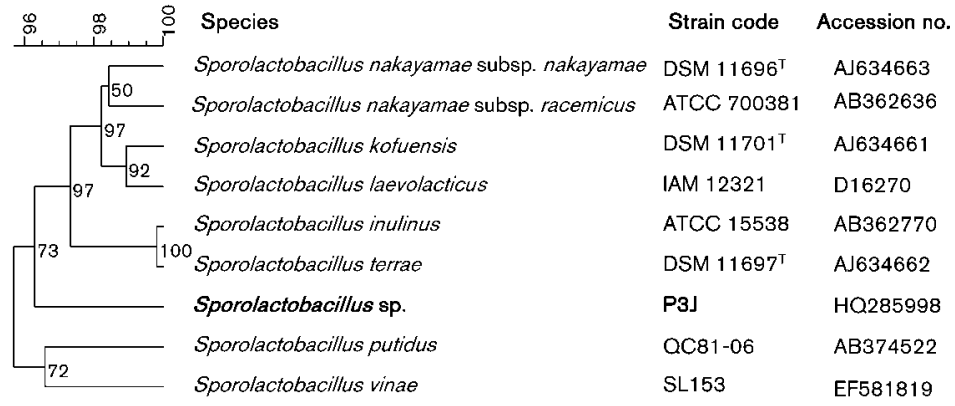

Fig. 1. Phylogenetic tree comparing partial $16 \mathrm{~S}$ rRNA gene sequences of Sporolactobacillus species described to date. The tree was constructed using the Pearson correlation and UPGMA (unweighted pair group method with arithmetic mean); bootstrap values are indicated at branch points (percentage of 1000 replicates). 
To test the influence of tyrosine (precursor amino acid) on the production of tyramine, GYP medium was supplemented with increasing concentrations of tyrosine (1, 5 and $10 \mathrm{mM}$ ). The final $\mathrm{OD}_{600}, \mathrm{pH}$ level and tyramine concentration were measured. The final tyramine concentration was higher as the intial tyrosine concentration in the cultures increased (Pearson coefficient 0.944, $P<0.01$ ) (Table 1). This tyramine production had no effect on growth, since no differences were observed in the final optical density reached by the cultures. However, a higher final $\mathrm{pH}$ was observed as more tyramine was synthesized (Pearson coefficient 0.750, $P<0.01$ ) (Table 1).

In order to determine if the presence of the $t d c$ operon is exclusive to the Sporolactobacillus sp. P3J strain or if it could be found in members of related species, we evaluated the presence of the $t d c$ operon in the type strains of S. kofuensis (DSM $17615^{\mathrm{T}}$ ), S. nakayamae subsp. nakayamae (DSM $11696^{\mathrm{T}}$ ), S. terrae (DSM $11697^{\mathrm{T}}$ ) and S. vineae $\left(\right.$ DSM $\left.21990^{\mathrm{T}}\right)$. None of them allowed for the amplification of the expected specific $t d c$ gene fragment (data not shown).

\section{Characterization of the $t d c$ region}

In order to determine the complete sequence of the Sporolactobacillus sp. P3J tyramine-production-associated genes, acquisition of the unknown DNA sequences adjacent to the $t d c$ fragment gene, in both the $5^{\prime}$ and $3^{\prime}$ directions, was performed by using an RS-PCR method based on the one proposed by Sarkar et al. (1993). The repetitive use of this method by the creation of new sets of primers based on each newly determined sequence allowed a 7535 bp nucleotide sequence to be obtained (GenBank accession no. HQ285999) from the original $1133 \mathrm{bp} t d c$ partial sequence. Sequence analysis of the fragment revealed the presence of four complete ORFs flanked by two partial ORFs (Table 2).

The first complete ORF (tyrS) consisted of $1167 \mathrm{bp}$ encoding 388 amino acids, and exhibited strong identities $(>77 \%)$ with known TyrS proteins, i.e. L. brevis

Table 1. Tyramine production according to different initial tyrosine concentrations

The same letter within a column indicates a statistically significant difference $(P<0.01)$ between the values, analysed by ANOVA and LSD analysis. Only differences between adjacent values are indicated.

\begin{tabular}{|lccc|}
\hline Medium & OD $_{\mathbf{6 0 0}}$ & $\mathbf{p H}$ & \multicolumn{1}{c|}{$\begin{array}{c}\text { Tyramine } \\
\text { concentration } \\
(\mathbf{m M})\end{array}$} \\
\hline GYP & $0.98 \pm 0.02$ & $4.13 \pm 0.01^{\mathrm{a}}$ & $0.09 \pm 0.03$ \\
GYP + 1 mM Tyr & $0.96 \pm 0.26$ & $4.27 \pm 0.04^{\mathrm{a}, \mathrm{b}}$ & $0.84 \pm 0.29^{\mathrm{a}}$ \\
GYP +5 mM Tyr & $0.97 \pm 0.12$ & $4.36 \pm 0.06^{\mathrm{b}, \mathrm{c}}$ & $2.48 \pm 0.32^{\mathrm{a}, \mathrm{b}}$ \\
GYP + 10 mM Tyr & $0.87 \pm 0.25$ & $4.44 \pm 0.05^{\mathrm{c}}$ & $8.92 \pm 1.56^{\mathrm{b}}$ \\
\hline
\end{tabular}

(YP_796295), E. faecium (ZP_06683270) and E. durans (CAF33979). Downstream of the tyrS gene, at an intergenic distance of $228 \mathrm{bp}$, a second ORF ( $t d c, 1920 \mathrm{bp}$ ) was observed. The translated sequence showed identities in the order of $64-76 \%$ with the tyrosine decarboxylases of tyramine-producing Gram-positive bacteria, i.e. L. brevis (ABY71221), E. hirae (AAQ73505), Staphylococcus epidermidis (ZP_04818142) and Tetragenococcus halophilus (BAD93616). The resulting putative protein of the third ORF ( $t y r P, 1464 \mathrm{bp}$ ), situated $65 \mathrm{bp}$ downstream of the $t d c$ gene, shared $80 \%$ sequence identity with the functionally characterized tyrosine permease (TyrP) of $L$. brevis (Wolken et al., 2006). Finally, 208 bp downstream of the putative tyrP gene, a fourth complete ORF ( $n h a C, 1410 \mathrm{bp}$ ) was observed. The putative encoded protein presented the highest level of identity with $\mathrm{Na}^{+} / \mathrm{H}^{+}$antiporters (NhaC) of L. brevis (ABY71223) and E. faecalis (ZP_05501989) (67 and $58 \%$, respectively).

On the sequenced fragment, the four genes associated with potential tyramine production are flanked upstream by a partial sequence (ter, $773 \mathrm{bp}$ ) presenting highest identities (71-75\%) in BLASTX analysis with putative phage terminases found in clostridia (i.e. YP_001308046, YP_003843917 and ZP_02630796). However, no start codon was observed and the ter sequence is directly attached to the ATG of the tyrS gene. Downstream, the $t d c$ operon was flanked, at $102 \mathrm{bp}$ of the end of the nhaC gene, by a partial sequence divergently encoding 65 amino acids that showed around $60 \%$ identity with a putative transposase found in LAB, i.e. Lactobacillus antri (ZP_05746645), O. oeni (ZP_01544598) and L. brevis subsp. gravesensis (ZP_03938918.1).

\section{Transcriptional analysis of the TDC operon}

To determine whether $t d c$ was co-transcribed with other genes of the TDC locus, total RNA of Sporolactobacillus sp. P3J was used in RT-PCRs with seven sets of primers designed to amplify individual genes as well as regions spanning gene junctions (Supplementary Table S1). Amplification products were obtained for each of the four targeted genes, while for the primers targeting gene junctions, only the $t d c-t y r P$ couple allowed for amplification, indicating that $t d c$ is cotranscribed with $t y r \mathrm{P}$ (Fig. 2).

The individual expression of the cluster genes was measured by RT-qPCR in either the presence $(10 \mathrm{mM})$ or absence of tyrosine. Since the expression of previously characterized $t d c$ clusters requires acidic conditions (Linares et al., 2009), the $\mathrm{pH}$ of the medium was adjusted to 5 . The results indicated that the expression of tyrS is independent of tyrosine, in contrast, a significant increase (Student's $t$-test $P<0.01$ ) in $t d c$, $t y r P$ and, to a lesser extent, nhaC expression was observed when tyrosine was added to the culture medium (Fig. 3). Tyramine concentration was also analysed by HPLC measurements in all cultures from which RNA was obtained, confirming that tyramine biosynthesis occurred at acidic $\mathrm{pH}$ in the presence of tyrosine (data not shown). 
Table 2. $t d c$ region putative encoded proteins

\begin{tabular}{|c|c|c|c|c|c|c|c|c|c|}
\hline Gene & $\begin{array}{c}\text { Location in } \\
\text { nucleotide } \\
\text { sequence }\end{array}$ & $\begin{array}{c}G+C \\
(\%)\end{array}$ & $\begin{array}{c}\text { Predicted } \\
\text { protein }(\mathrm{aa} / \\
\mathrm{kDa} / \mathrm{pI})^{\star}\end{array}$ & $\begin{array}{c}\text { Conserved } \\
\text { domain } \dagger\end{array}$ & $\begin{array}{l}\text { Closest protein } \\
\text { (aa) }\end{array}$ & $\begin{array}{l}\text { Proposed } \\
\text { function }\end{array}$ & $\begin{array}{l}\text { Identity } \\
(\%) \neq\end{array}$ & Accesssion no. & Organism \\
\hline$t d c$ & 2169-4088 & 40.7 & $639 / 72.1 / 5.09$ & $\begin{array}{c}\text { Tyrosine } \\
\text { decarboxylase } \\
\text { family }\end{array}$ & $\begin{array}{c}\text { Tyrosine } \\
\text { decarboxylase }\end{array}$ & $\begin{array}{c}\text { Tyrosine } \\
\text { decarboxylase }\end{array}$ & 76 & YP_796294 & $\begin{array}{l}\text { L. brevis } \\
\text { ATCC } 367\end{array}$ \\
\hline tyr $P$ & $4154-5617$ & 39.5 & $487 / 53.5 / 9.96$ & $\begin{array}{c}\text { Amino acid } \\
\text { permease }\end{array}$ & $\begin{array}{c}\text { Putative tyrosine } \\
\text { permease }\end{array}$ & $\begin{array}{c}\text { Tyrosine/tyramine } \\
\text { antiporter }\end{array}$ & 80 & YP_796293 & $\begin{array}{l}\text { L. brevis } \\
\text { ATCC } 367\end{array}$ \\
\hline rev & $7338-7535$ & 42.4 & Partial & $\begin{array}{c}\text { Putative } \\
\text { transposase orf } B\end{array}$ & $\begin{array}{l}\text { Conserved } \\
\text { hypothetical } \\
\text { protein }\end{array}$ & Transposase & 60 & ZP_05746645 & $\begin{array}{c}\text { L. antri DSM } \\
16041\end{array}$ \\
\hline
\end{tabular}

*Theoretical molecular mass and pI were estimated by using the Compute pI/Mw tool (http://www.expasy.ch/tools/pi_tool.html). $\dagger$ Identified by the NCBI Conserved Domain Search tool (http://www.ncbi.nlm.nih.gov/Structure/cdd/wrpsb.cgi).

\#Identical amino acid percentage between the predicted sequence and the closest sequence in GenBank using BLASTP.

\section{Functional expression of tyrP in L. lactis}

The tyrP gene was cloned in the NICE system expression vector pNZ8048, yielding pNZtyrP-Sp, for nisin-inducible expression in L. lactis NZ9000 (de Ruyter et al., 1996). Resting cells of L. lactis harbouring pNZtyrP-Sp or the empty vector pNZ8048 were assayed for tyrosine and tyramine uptake using ${ }^{14} \mathrm{C}$-labelled tyrosine and tyramine, respectively (Fig. 4). At $1.15 \mu \mathrm{M}{ }^{14} \mathrm{C}$-labelled tyrosine, there was no increase in tyrosine uptake of cells expressing tyrP compared with control cells showing the background tyrosine uptake mediated by an endogenous tyrosine transport system(s). However, when an approximately 900 -fold excess of unlabelled tyramine was added to cells that were allowed to take up ${ }^{14} \mathrm{C}$-labelled tyrosine for $1 \mathrm{~min}$, cells expressing tyrP rapidly released tyrosine, whereas control cells did not (Fig. 4a), demonstrating tyrosine/tyramine exchange via TyrP.

Control cells harbouring the pNZ8048 vector did not take up significant amounts of ${ }^{14} \mathrm{C}$-labelled tyramine at $18 \mu \mathrm{M}$. Under the same conditions, cells expressing tyrP showed a low, but significant, level of uptake (Fig. 4b). However, tyramine uptake was strongly increased to an initial rate of higher than $100 \mathrm{nmol} \mathrm{min}{ }^{-1} \mathrm{mg}^{-1}$ when cells were incubated for $1 \mathrm{~h}$ with a high concentration $(5 \mathrm{mM})$ of tyrosine prior to the uptake experiment. In contrast, control cells did not show a significant increase in uptake. The reverse experiment, preincubation of cells expressing

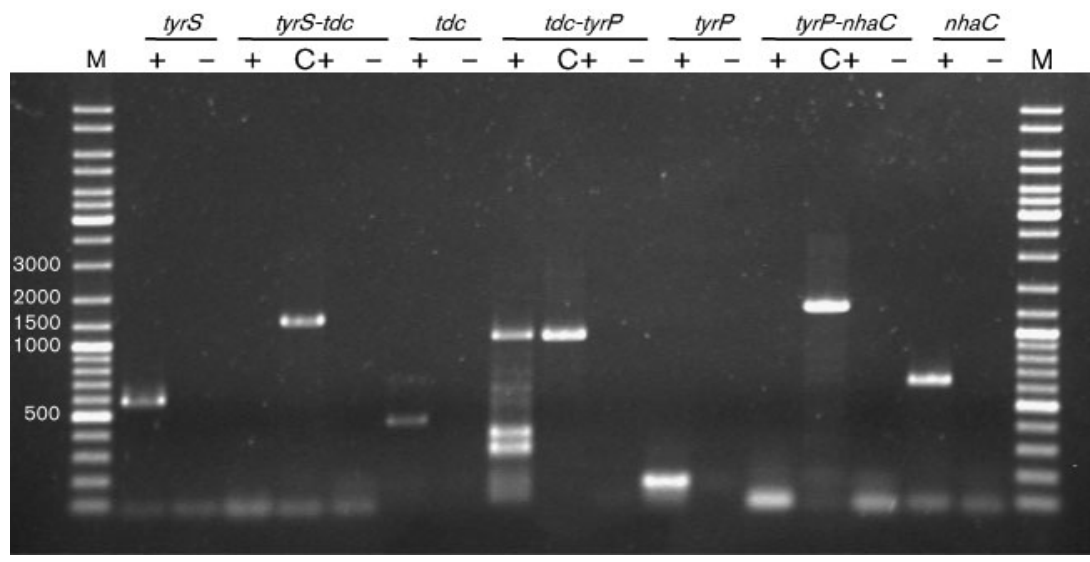

Fig. 2. RT-PCR amplification with primers designed to amplify the genes and the intergenic regions of tyrS, tyrS-tdc, tdc, tdc-tyrP, tyrP, tyrP-nhaC and nhaC. PCR was carried out on samples treated $(+)$ or not $(-)$ with reverse transcriptase. PCR performed using chromosomal DNA as a template $(\mathrm{C}+)$ was only included for the intergenic region analysis. M, Molecular mass markers (FastRuler lowrange DNA ladder; Fermentas); sizes given in bp. 


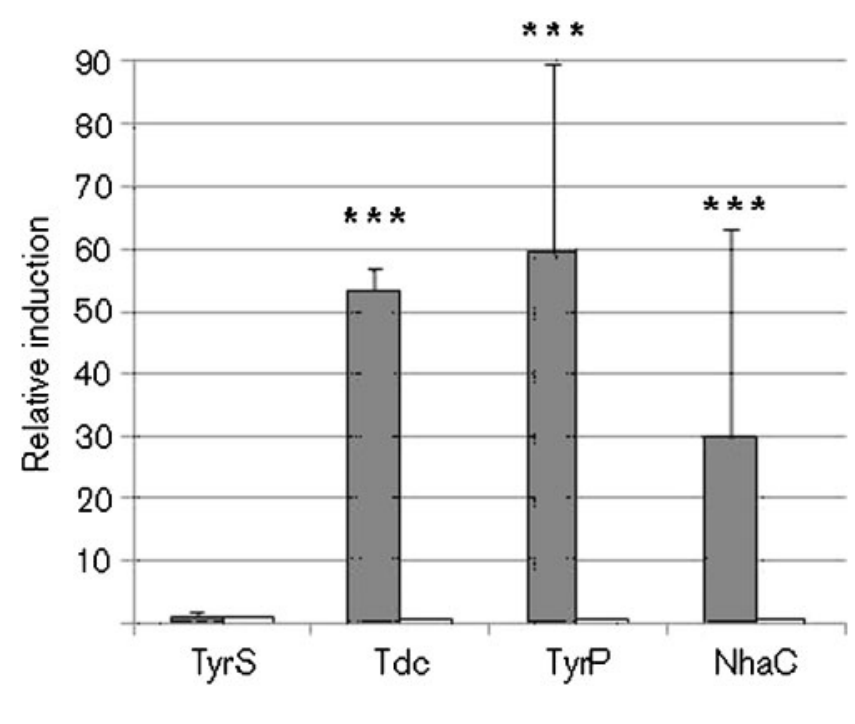

Fig. 3. Effect of tyrosine on the expression level of tyrS, tdc, tyrP and $n h a C$ from Sporolactobacillus sp. cells grown in GYP medium either in the absence (white bars) or presence (grey bars) of $10 \mathrm{mM}$ tyrosine. Each value is the mean \pm SD of three independent experiments. ${ }^{\star \star \star} P<0.01$.

tyrP with a high concentration of tyramine, did not result in a higher uptake of tyrosine (data not shown), suggesting that tyramine did not accumulate in the cells during the preincubation period. Taken together, the results indicate that $\operatorname{tyr} P$ was functionally expressed and that its product catalyses the exchange of tyrosine and tyramine.

\section{DISCUSSION}

Identification of the cider isolate P3J indicated that it belonged to the Sporolactobacillus genus, thus explaining the observations that it was a Gram-positive catalasenegative bacterium presenting an endospore in terminal position. The identity levels observed did not allow for presumptive assigning of the $\mathrm{P} 3 \mathrm{~J}$ isolate to a defined species and suggested that it might actually correspond to a novel species within the Sporolactobacillus genus.

Sporolactobacilli represent an interesting genus from a morphological, physiological and evolutionary point of view as they correspond to intermediate forms between the homo-fermentative Lactobacillus group and the Bacillus genus (Kitahara \& Suzuki, 1963). Sporolactobacilli have been associated with fermentation starters for Asian alcoholic beverages (Yanagida et al., 1997), wine grapes (Bae et al., 2006) and the associated environments (Yanagida et al., 2005; Chang et al., 2008), as well as spoiled orange juice (Fujita et al., 2010) and the extreme environment of sugar thick juice (Justé et al., 2008). To our knowledge, this study is the first description of a bacterium associated with cider production that belongs to the Sporolactobacillus genus.

Concerning the presence of the TDC pathway in Sporolactobacillus sp. P3J, the genetic and phenotypic results obtained here indicate that the presence of a specific PCR amplification product was correlated with the production of tyramine in the tested conditions. Regarding the Sporolactobacillus sp. P3J TDC pathway, its genetic organization, consisting of four genes [in the following order: tyrosyl-tRNA synthetase gene (tyrS), tyrosine decarboxylase $(t d c)$, tyrosine permease $(\operatorname{tyr} P)$ and an $\mathrm{Na}^{+} / \mathrm{H}^{+}$antiporter (nhaC)] corresponded to that already described in various LAB including $L$. brevis (Lucas et al., 2003), E. faecalis (Connil et al., 2002), E. hirae (Coton et al., 2004), E. durans (Fernández et al., 2004), E. faecium (GenBank accession no. NZ_AAAK00000000). In $T$. halophilus, the same type of organization was observed with the exception that the tyrS gene was absent in this species (GenBank accession no. AB059363). TyrS of Sporolactobacillus sp. P3J showed the highest identities (75-78\%) with TyrS associated with $t d c$ pathways supporting the existence of two categories of TyrS, one for general metabolism and one associated with tyramine production as suggested by Coton \& Coton (2009) in $L$.
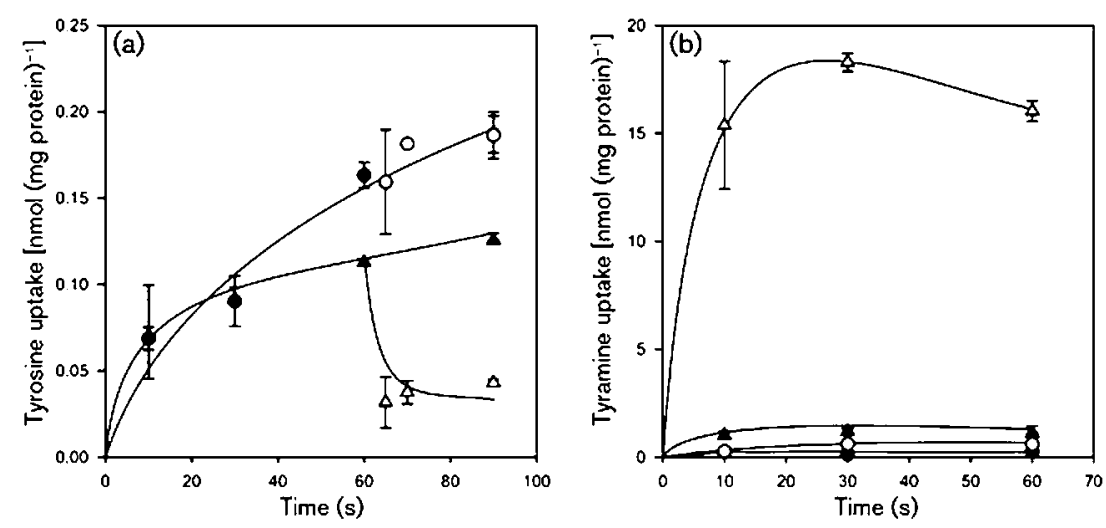

Fig. 4. Tyrosine (a) and tyramine (b) uptake in L. lactis $\mathrm{NZ9000}$ harbouring pNZtyrP-Sp (triangles) and pNZ8048 (circles). Cells were induced with $5 \mathrm{ng}$ nisin $\mathrm{ml}^{-1}$ for $1 \mathrm{~h}$ for tyrP expression. ${ }^{14} \mathrm{C}$-Labelled tyrosine and ${ }^{14} \mathrm{C}$ labelled tyramine were added to final concentrations of 1.15 and $18 \mu \mathrm{M}$, respectively. (a) Tyrosine uptake. After $1 \mathrm{~min}$, cells were either left untreated (closed symbols) or unlabelled tyramine was added to a concentration of $1 \mathrm{mM}$ (open symbols). (b) Tyramine uptake was measured in cells preincubated for $1 \mathrm{~h}$ in $100 \mathrm{mM} \mathrm{KPi}$ buffer, pH 6.0, without (closed symbols) or with (open symbols) $5 \mathrm{mM}$ tyrosine followed by washing with $100 \mathrm{mM} \mathrm{KPi}$ buffer, $\mathrm{pH}$ 6.0. 
brevis. Interestingly, the analysis of tyrS indicated that the reverse complement sequence of the first 22 bases was associated with clostridial phage terminases, thus suggesting that the integration of the $t d c$ operon was done at this site due to sequence homologies and hence disrupted the phage terminase gene (ter).

It is noteworthy that the genes surrounding the tyramine production operon (ter upstream and rev downstream) correspond to putative mobility genes, suggesting that the tyramine production ability in Sporolactobacillus sp. P3J might have been acquired through horizontal gene transfer (HGT). Some authors have already shown that BAproduction-associated pathways are often associated with mobile elements (i.e. plasmids and genomic islands) and therefore have been acquired through HGT, explaining strain to strain variation in the ability to produce BA. On one hand, plasmids harbouring BA production operons have been shown to be responsible for the production of histamine in L. hilgardii (Lucas et al., 2005) and T. halophilus (Satomi et al., 2008) as well as, recently, for the production of putrescine from ornithine in Staphylococcus epidermidis (Coton et al., 2010a). On the other hand, putative genomic islands harbouring BA production operons have been described as being responsible for production of putrescine (from ornithine) in O. oeni (Marcobal et al., 2006) and of tyramine in L. brevis (Coton \& Coton, 2009).

The fact that no amplification of the $t d c$ gene was observed in four strains of the Sporolactobacillus genus suggests that the ability to produce tyramine is rather exclusive to Sporolactobacillus sp. strain P3J, which is also in agreement with trait acquisition through HGT.

Interestingly, the ter gene presented the highest identities with putative phage terminases from sporulated bacteria belonging to the Clostridium and Bacillus genera, while the rev mobility gene presented the highest identities with putative transposases from $\mathrm{LAB}$ belonging to the Lactobacillus, Oenococcus and Enterococcus genera. These results were thus in agreement with the fact that sporolactobacilli share common traits with both sporulated and lactic acid bacteria, and suggested that genetic material exchange can occur with both bacterial groups.

Transcription analyses of the $t d c$ gene cluster suggested that tyrS and $n h a C$ are expressed as monocistronic genes, while $t d c$ would be part of a polycistronic mRNA together with tyrP. These results were in agreement with the fact that a terminator $(14.9 \mathrm{Kcal})$ sequence was present on the Sporolactobacillus sp. P3J sequence between tyrP and $n h a C$. In addition, they were consistent with what was observed in E. durans IPLA655, in which $t d c$ and tyrP were also cotranscribed (Linares et al., 2009) and in L. brevis, in which a strong signal of the $t d c-t y r P$ product indicated that RNAs containing these two genes were probably abundant, although other amplification products $(t y r S-t d c$ and $t y r P-$ $n h a C)$ were also obtained (Lucas et al., 2003).
The expression of the cluster genes measured by RT-qPCR indicated that the expression of $t d c$ and $t y r P$ was induced in the presence of tyrosine. These results were in agreement with the fact that the expression of decarboxylase genes has been linked to the presence of an amino acid substrate in bacteria (Soksawatmaekhin et al., 2004; Linares et al., 2009). Only when there is an excess of amino acid substrate do the bacteria use it for the decarboxylation reaction, thus ensuring its availability for protein biosynthesis. The $n h a C$ gene was also induced by tyrosine, in contrast with tyrS, raising the question about the role of this gene in the $t d c$ operon. However, to date, a specific tyrS gene has always been identified as being linked to the $t d c$ gene clusters described in LAB (Connil et al., 2002; Lucas et al., 2003; Coton et al., 2004; Fernández et al., 2004) except in $T$. halophilus (GenBank accession no. AB059363). Moreover, in tyramine-producing strains such as E. faecalis V583 or $L$. brevis ATCC 357 in which the entire genome has been sequenced (GenBank accession nos NC_004668 and NC_008497, respectively), a second tyrS gene can be identified in addition to the $t y r S$ gene of the $t d c$ cluster.

Concerning transport assays, expression of the tyrP gene of Sporolactobacillus sp. P3J in L. lactis identified TyrP as a tyrosine/tyramine exchanger. Precursor/product exchangers of this type function in catabolic amino acid decarboxylation pathways, many of which have been described previously (Molenaar et al., 1993; Kashiwagi et al., 1997; Iyer et al., 2003). TyrP of Sporolactobacillus sp. $\mathrm{P} 3 \mathrm{~J}$ is the second tyrosine/tyramine exchanger to be cloned and kinetically characterized. The transporter protein shares $80 \%$ amino acid sequence identity with TyrP of L. brevis which was the first one to be characterized (Wolken et al., 2006). L. brevis TyrP showed a much higher initial tyrosine uptake activity than the Sporolactobacillus sp. P3J TyrP in comparable uptake experiments in which ${ }^{14} \mathrm{C}$-labelled tyrosine was added to resting cells. Nevertheless, tyrosine/tyramine exchange occurred rapidly with both TyrPs (Fig. 4). The reason for the much lower tyrosine uptake via Sporolactobacillus sp. P3J TyrP is unclear. Possible modes of tyrosine uptake via TyrP in these experiments are exchange with intracellular tyrosine or proton/tyrosine symport. The latter is unlikely since no proton motive force-driven tyrosine uptake was observed for L. brevis TyrP. Instead, tyrosine uniport was identified as a second mode of transport in addition to tyrosine/ tyramine exchange catalysed by L. brevis TyrP by tyrosine efflux from membrane vesicles loaded with ${ }^{14} \mathrm{C}$-labelled tyrosine, while the results on tyramine uniport were inconclusive (Wolken et al., 2006). The uniport transport mode was not observed in the present study. Energized cells of L. lactis expressing TyrP did not show much higher levels of accumulation of positively charged ${ }^{14} \mathrm{C}$-labelled tyramine than the control cells. Moreover, cells could not be efficiently loaded with unlabelled tyramine, while this was successful for tyrosine (Fig. 4b). Endogenous tyrosine transporters of $L$. lactis were most likely responsible for loading in the latter case. The low level of tyramine uptake 
without tyrosine preloading probably results from exchange with an internal pool of tyrosine, as reported by Kunji et al. (1996).

The physiological role of biogenic amine formation is not yet fully understood although some authors have proposed that decarboxylation pathways could be involved in resistance against acid stress (Azcarate-Peril et al., 2004) and/or generation of energy (Cid et al., 2008; Pereira et al., 2009). In this study, the ability of Sporolactobacillus sp. P3J to produce tyramine under acidic conditions in the presence of tyrosine is demonstrated. These conditions are inherent to fermented products such as cider, from which this strain was isolated. Results obtained in the presence of increasing initial concentrations of tyrosine revealed a correlation with increasing tyramine production with a concomitant increase in the final $\mathrm{pH}$ reached by the culture (Table 1), which was expected as the decarboxylation releases an acidic function. This could be in agreement with the proposed role as an acidic resistance mechanism for the TDC pathway. However, the fact that no differences were observed in the final optical density does not demonstrate an increased biological fitness. In this context, the incidence of the presence of the $t d c$ operon on the adaptability and growth of Sporolactobacillus sp. P3J in various environmental conditions, including cider conditions characterized by low $\mathrm{pH}$, should be investigated further.

\section{ACKNOWLEDGEMENTS}

The authors are thankful to Cécile Desmarais for technical assistance. This work was funded by the European Community's Seventh Framework Program, in the framework of the BIAMFOOD project (Controlling Biogenic Amines in Traditional Food Fermentations in Regional Europe, project no. 211441).

\section{REFERENCES}

Altschul, S. F., Gish, W., Miller, W., Myers, E. W. \& Lipman, D. J. (1990). Basic local alignment search tool. J Mol Biol 215, 403-410.

Azcarate-Peril, M. A., Altermann, E., Hoover-Fitzula, R. L., Cano, R. J. \& Klaenhammer, T. R. (2004). Identification and inactivation of genetic loci involved with Lactobacillus acidophilus acid tolerance. Appl Environ Microbiol 70, 5315-5322.

Bae, S., Fleet, G. H. \& Heard, G. M. (2006). Lactic acid bacteria associated with wine grapes from several Australian vineyards. J Appl Microbiol 100, 712-727.

Bover-Cid, S., Torriani, S., Gatto, V., Tofalo, R., Suzzi, G., Belletti, N. \& Gardini, F. (2009). Relationships between microbial population dynamics and putrescine and cadaverine accumulation during dry fermented sausage ripening. J Appl Microbiol 106, 1397-1407.

Burdychova, R. \& Komprda, T. (2007). Biogenic amine-forming microbial communities in cheese. FEMS Microbiol Lett 276, 149155.

Caston, J. C., Eaton, C. L., Gheorghiu, B. P. \& Ware, L. L. (2002). Tyramine induced hypertensive episodes and panic attacks in hereditary deficient monoamine oxidase patients: case reports. J S C Med Assoc 98, 187-192.
Chang, S. F., Ayres, J. W. \& Sandine, W. E. (1985). Analysis of cheese for histamine, tyramine, tryptamine, histidine, tyrosine, and tryptophane. J Dairy Sci 68, 2840-2846.

Chang, Y. H., Jung, M. Y., Park, I. S. \& Oh, H. M. (2008). Sporolactobacillus vineae sp. nov., a spore-forming lactic acid bacterium isolated from vineyard soil. Int J Syst Evol Microbiol 58, 2316-2320.

Chen, Y. S., Yanagida, F. \& Shinohara, T. (2005). Isolation and identification of lactic acid bacteria from soil using an enrichment procedure. Lett Appl Microbiol 40, 195-200.

Cid, S. B., Miguélez-Arrizado, M. J., Becker, B., Holzapfel, W. H. \& Vidal-Carou, M. C. (2008). Amino acid decarboxylation by Lactobacillus curvatus CTC273 affected by the $\mathrm{pH}$ and glucose availability. Food Microbiol 25, 269-277.

Connil, N., Le Breton, Y., Dousset, X., Auffray, Y., Rincé, A. \& Prévost, H. (2002). Identification of the Enterococcus faecalis tyrosine decarboxylase operon involved in tyramine production. Appl Environ Microbiol 68, 3537-3544.

Coton, E. \& Coton, M. (2005). Multiplex PCR for colony direct detection of Gram-positive histamine- and tyramine-producing bacteria. J Microbiol Methods 63, 296-304.

Coton, E. \& Coton, M. (2009). Evidence of horizontal transfer as origin of strain to strain variation of the tyramine production trait in Lactobacillus brevis. Food Microbiol 26, 52-57.

Coton, M., Coton, E., Lucas, P. \& Lonvaud, A. (2004). Identification of the gene encoding a putative tyrosine decarboxylase of Carnobacterium divergens 508. Development of molecular tools for the detection of tyramine-producing bacteria. Food Microbiol 21, 125130.

Coton, E., Mulder, N., Coton, M., Pochet, S., Trip, H. \& Lolkema, J. S. (2010a). Origin of the putrescine-producing ability of the coagulasenegative bacterium Staphylococcus epidermidis 2015B. Appl Environ Microbiol 76, 5570-5576.

Coton, M., Romano, A., Spano, G., Ziegler, K., Vetrana, C., Desmarais, C., Lonvaud-Funel, A., Lucas, P. \& Coton, E. (2010b). Occurrence of biogenic amine-forming lactic acid bacteria in wine and cider. Food Microbiol 27, 1078-1085.

de Ruyter, P. G., Kuipers, O. P. \& de Vos, W. M. (1996). Controlled gene expression systems for Lactococcus lactis with the food-grade inducer nisin. Appl Environ Microbiol 62, 3662-3667.

Desroche, N., Beltramo, C. \& Guzzo, J. (2005). Determination of an internal control to apply reverse transcription quantitative PCR to study stress response in the lactic acid bacterium Oenococcus oeni. J Microbiol Methods 60, 325-333.

Edwards, U., Rogall, T., Blöcker, H., Emde, M. \& Böttger, E. C. (1989). Isolation and direct complete nucleotide determination of entire genes. Characterization of a gene coding for $16 \mathrm{~S}$ ribosomal RNA. Nucleic Acids Res 17, 7843-7853.

Fernández, M., Linares, D. M. \& Alvarez, M. A. (2004). Sequencing of the tyrosine decarboxylase cluster of Lactococcus lactis IPLA 655 and the development of a PCR method for detecting tyrosine decarboxylating lactic acid bacteria. J Food Prot 67, 2521-2529.

Fritz, G., Koller, C., Burdack, K., Tetsch, L., Haneburger, I., Jung, K. \& Gerland, U. (2009). Induction kinetics of a conditional $\mathrm{pH}$ stress response system in Escherichia coli. J Mol Biol 393, 272-286.

Fujita, R., Mochida, K., Kato, Y. \& Goto, K. (2010). Sporolactobacillus putidus sp. nov., an endospore-forming lactic acid bacterium isolated from spoiled orange juice. Int J Syst Evol Microbiol 60, 1499-1503.

Garai, G., Dueñas, M. T., Irastorza, A., Martín-Alvarez, P. J. \& Moreno-Arribas, M. V. (2006). Biogenic amines in natural ciders. J Food Prot 69, 3006-3012. 
Garai, G., Dueñas, M. T., Irastorza, A. \& Moreno-Arribas, M. V. (2007). Biogenic amine production by lactic acid bacteria isolated from cider. Lett Appl Microbiol 45, 473-478.

Iyer, R., Williams, C. \& Miller, C. (2003). Arginine-agmatine antiporter in extreme acid resistance in Escherichia coli. J Bacteriol 185, 65566561.

Justé, A., Lievens, B., Frans, I., Klingeberg, M., Michiels, C. W. \& Willems, K. A. (2008). Present knowledge of the bacterial microflora in the extreme environment of sugar thick juice. Food Microbiol 25, 831-836.

Kashiwagi, K., Shibuya, S., Tomitori, H., Kuraishi, A. \& Igarashi, K. (1997). Excretion and uptake of putrescine by the PotE protein in Escherichia coli. J Biol Chem 272, 6318-6323.

Kitahara, K. \& Suzuki, J. (1963). Sporolactobacillus nov. subgen. J Gen Appl Microbiol 9, 59-71.

Krause, I., Bockhardt, A., Neckermann, H., Henle, T. \& Klostermeyer, H. (1995). Simultaneous determination of amino acids and biogenic amines by reversed-phase high-performance liquid chromatography of the dabsyl derivatives. J Chromatogr 715, 67-79.

Kunji, E. R., Mierau, I., Hagting, A., Poolman, B. \& Konings, W. N. (1996). The proteolytic systems of lactic acid bacteria. Antonie van Leeuwenhoek 70, 187-221.

Ladero, V., Calles-Enriquez, M., Fernández, M. \& Alvarez, M. A. (2010). Toxicological effects of dietary biogenic amines. Curr Nut Food Sci 6, 145-156.

Linares, D. M., Fernández, M., Martín, M. C. \& Alvarez, M. A. (2009). Tyramine biosynthesis in Enterococcus durans is transcriptionally regulated by the extracellular $\mathrm{pH}$ and tyrosine concentration. Microb Biotechnol 2, 625-633.

Livak, K. J. \& Schmittgen, T. D. (2001). Analysis of relative gene expression data using real-time quantitative PCR and the $2^{-\Delta} \Delta$ CT method. Methods 25, 402-408.

Lonvaud-Funel, A. (2001). Biogenic amines in wines: role of lactic acid bacteria. FEMS Microbiol Lett 199, 9-13.

Lucas, P., Landete, J., Coton, M., Coton, E. \& Lonvaud-Funel, A. (2003). The tyrosine decarboxylase operon of Lactobacillus brevis IOEB 9809: characterization and conservation in tyramine-producing bacteria. FEMS Microbiol Lett 229, 65-71.

Lucas, P. M., Wolken, W. A., Claisse, O., Lolkema, J. S. \& LonvaudFunel, A. (2005). Histamine-producing pathway encoded on an unstable plasmid in Lactobacillus hilgardii 0006. Appl Environ Microbiol 71, 1417-1424.

Marcobal, A., de las Rivas, B., Moreno-Arribas, M. V. \& Muñoz, R. (2006). Evidence for horizontal gene transfer as origin of putrescine production in Oenococcus oeni RM83. Appl Environ Microbiol 72, 7954-7958.
Molenaar, D., Bosscher, J. S., ten Brink, B., Driessen, A. J. \& Konings, W. N. (1993). Generation of a proton motive force by histidine decarboxylation and electrogenic histidine/histamine antiport in Lactobacillus buchneri. J Bacteriol 175, 2864-2870.

Moon, J. S., Cho, S. K., Choi, H. Y., Kim, J. E., Kim, S. Y., Cho, K. J. \& Han, N. S. (2010). Isolation and characterization of biogenic amineproducing bacteria in fermented soybean pastes. J Microbiol 48, 257261.

Pereira, C. I., San Romão, M. V., Lolkema, J. S. \& Crespo, M. T. (2009). Weissella halotolerans W22 combines arginine deiminase and ornithine decarboxylation pathways and converts arginine to putrescine. J Appl Microbiol 107, 1894-1902.

Sarkar, G., Turner, R. T. \& Bolander, M. E. (1993). Restriction-site PCR: a direct method of unknown sequence retrieval adjacent to a known locus by using universal primers. PCR Methods Appl 2, 318322.

Satomi, M., Furushita, M., Oikawa, H., Yoshikawa-Takahashi, M. \& Yano, Y. (2008). Analysis of a $30 \mathrm{kbp}$ plasmid encoding histidine decarboxylase gene in Tetragenococcus halophilus isolated from fish sauce. Int J Food Microbiol 126, 202-209.

Soksawatmaekhin, W., Kuraishi, A., Sakata, K., Kashiwagi, K. \& Igarashi, K. (2004). Excretion and uptake of cadaverine by CadB and its physiological functions in Escherichia coli. Mol Microbiol 51, 14011412.

Suzzi, G. \& Gardini, F. (2003). Biogenic amines in dry fermented sausages: a review. Int J Food Microbiol 88, 41-54.

ten Brink, B., Damink, C., Joosten, H. M. \& Huis in 't Veld, J. H. (1990). Occurrence and formation of biologically active amines in foods. Int J Food Microbiol 11, 73-84.

Wallace, H. M. (2007). Health Implications of Dietary Amines: an overview of COST Action 922 (2001-2006). Biochem Soc Trans 35, 293-294.

Wolken, W. A., Lucas, P. M., Lonvaud-Funel, A. \& Lolkema, J. S. (2006). The mechanism of the tyrosine transporter TyrP supports a proton motive tyrosine decarboxylation pathway in Lactobacillus brevis. J Bacteriol 188, 2198-2206.

Yanagida, F., Suzuki, K. I., Kozaki, M. \& Komagata, K. (1997). Proposal of Sporolactobacillus nakayamae subsp. nakayamae sp. nov., subsp. nov., Sporolactobacillus nakayamae subsp. racemicus subsp. nov., Sporolactobacillus terrae sp. nov., Sporolactobacillus kofuensis sp. nov., and Sporolactobacillus lactosus sp. nov. Int J Syst Bacteriol 47, 499-504.

Yanagida, F., Chen, Y. S. \& Shinohara, T. (2005). Isolation and characterization of lactic acid bacteria from soils in vineyards. J Gen Appl Microbiol 51, 313-318.

Edited by: D. A. Mills 